\title{
The Antiparalleling Statute: A New Dimension in Public Utility Condemnation
}

\author{
Stuart R. Pollak* and Howard M. Downs* ${ }^{* *}$
}

In 1965 the California Legislature enacted a new type of legislation in the field of public utility condemnation. By sections 1500-06 of the Public Utilities Code, ${ }^{1}$ the legislature granted privately owned water companies the right to be paid just compensation for the diminution in the value of their property occurring as a result of the duplication of their facilities by a political subdivision, such as a nnunicipal or county water district. The legislation is significant because of the growing trend for public water agencies to replace investor-owned and mutual water companies and because it reflects an expanding acceptance of public responsibility for private injury resulting from governmental action pursued in the nanie of the common good.

In Cucamonga County Water District v. Southwest Water Co.," the legislation received its judicial baptism. Although acquiring a significant judicial gloss, the statute withstood constitutional challenge. And the procedures developed for the trial of the action-which received only slight attention from the court of appeal-illumimate numerous problems arising out of the poor draftsinanship with which the statute is infected. Thus, while the validity of the new legislation inust be regarded as established, numerous questions of substance and procedure remain for future determination.

\section{PURPOSE OF THE LEgISLATION}

The reasons for which the 1965 legislation was necessary are grounded both in the economics of public utility operations and the

* B.A. 1959, Stanford University; LL.B. 1962, Harvard University.

** B.A. 1950, De Pauw University; J.D. 1956, University of Michigan.

The authors were counsel for the respondents, Southwest Water Co. and Rochester Water Co., in Cucamonga County Water District v. Southwest Water Co., discussed herein. Many of the approaches discussed in this article are significantly attributable to the wisdom and patience of Judge Carl B. Hilliard, who presided over the trial.

1. Cal. Pub. UTII. Code ANn. $\$ \$ 1500-06$ (West Supp. 1972).

2. 22 Cal. App. 3d 245, 99 Cal Rptr. 557 (4th Dist. 1971). 
statutory and administrative scheme that has developed for their regulation. Privately owned utilities, such as water companies, are subject to regulation by the California Public Utilities Commission (PUC). ${ }^{3}$ Because of the diseconomy that would necessarily be involved were more than one utility to serve an area, the commission normally authorizes but a single company to serve a given area. The commission will grant a certificate of public convenience and necessity to a second utility to serve the same area only if it finds that public need requires such duplication; ${ }^{4}$ the economic realities of public utility operation virtually assure that no such finding can be made. ${ }^{5}$

While administrative regulation thus normally assures that an existing utility will not face uneconomic competiton in its service area, all phases of its operations are subject to regulation and control by the regulatory agency. Its properties are dedicated to the public use. The utility is obliged to provide water service to all customers within its service area who desire service. Its rates are regulated by the PUC, and the rates are based on the premise that the utility will not face outside competition in its area and that the facilities used in its operations will remaim useful for their entire pliysical life. In areas that are not yet fully developed, the regulation by the commission therefore often means that a utility will incur losses for a period of years, with the expectation that the costs of the utility's facilities will be recovered in subsequent years as the area develops. ${ }^{6}$

3. Cal. Const. art. 12, \$23; Cal. Pub. Utul. Code Ann. \$\$451 et seq. (West 1965).

4. Monterey Peninsula Municipal Water Dist., 63 Cal. P.U.C. 533, 537 (1964); Super-Temp Corp. v. Suburban Water Systems, 61 Cal. P.U.C. 385, 386 (1963).

5. Phillips, The Economics of Regulation 19-44 (1965); 1 A. Priest, Principles of Public Utility Regulation 347-49, 375-77 (1969).

6. Cal. Pub. UtIL. Code ANN. $\$ 1501$ (West Supp. 1972). One of the few pieces of legislative history on the statute may be found in a letter from Senator Randolph Collier, its author, to Governor Brown, urging his consideration of the Senate Bill embodying the act. The letter, pointing out the facts discussed above, reads as follows:

Dear Pat:

I earnestly request your consideration of SB 687 .

SB 687 is a bill which will provide the legal process whereby a private utility water company may avail itself of eminent domain proceedings in court for the purpose of having the value of its loss determined when it is taken over in part or totally by a public entity.

A private utility water company is a creature of and operates under the certificate of public convenience and necessity granted to it by the Public Utilities Commission. Its rates and its standards of service are fixed by the Public Utilities Commission.

It can only operate within the area allotted to it by the Public Utilities Commission but it must serve auy and all customers in that area.

A publiciy owned water utility operates under a constitutional provision and is not subject to any control or jurisdictiou by the Public Utilities Commission.

It may therefore serve at random or at will and may invade or take over the area of a private utility company. 
Political subdivisions, however, are not subject to the authority of the PUC. ${ }^{7}$ Therefore, a municipal or county water district, upon obtaining the necessary voter approval and complying with the prescribed statutory procedures, may expand into an area served by a privately owned water company. ${ }^{8}$ The political subdivision may extend its service by acquiring the facilities of the existing private utility under its power of eminent domain; ${ }^{9}$ or the subdivision can construct its own facilities, paralleling or duplicating the existing facilities of the private utility.

There are several reasons for which a public water agency might prefer to duplicate rather than condemn and utilize the existing facilities. If the existing system is in need of expansion or improvement, the public agency may prefer designing an entirely new system to building from the existing system. The cost of new construction may be little or no more expensive than utilizing and improving the existing system, if no consideration is given to the private utility's investment. So long as the public agency need not be concerned with the loss arising from the forced obsolescence of the existmg system, this consideration need not enter its economic calculations. Moreover, by threatening to parallel rather than condemn, the public district may be able to negotiate the price for which the private water company will sell its facilities to one below the fair market value that would be obtained in condemnation proceedings. Experience in California prior to the enactinent of the legislation demonstrated the reality of such possibilities. ${ }^{10}$

SB 687 will not and could not in any way prevent such activity. It only provides a means whereby the private utility may get into court on an eminent domain basis for the purpose of having the court determine the value of any loss it may sustain through loss of its business by the invasion of the public entity. The amount of loss may be negotiated by the parties in which case no court action would be necessary.

It is obvious that in any court proceeding between a private utility water company and a public entity the court would be more plausibly swayed by the public body than by the private company.

Section 1505 (Page 3), provides that the private utility water company will be subject to the same conditions if it invades the territory of the public entity, thus making it a two way street.

Kindest personal regards.

RANDOLPH COLLIER

See also, Monterey Peninsula Municipal Water Dist., 63 Cal. P.U.C. 533, 537 (1964).

7. Only private corporations, individuals, and associations of individuals are subject to regulation by the PUC. CAL. CONST. art. XII, $\$ 23$.

8. Cuark v. Los ANGeles, 160 Cal. 30, 39, 116 P. 722, 725 (1911).

9. Cal. Water Code AnN. \& 31044 (West 1956); Cal. Code Ctv. Pro. \$ 1238 (West 1970); see Citizen's Util. Co. v. Superior Court, 59 Cal. 2d 805, 815, 382 P.2d 356, 363, 31 Cal. Rptr. 316, 323 (1963); Sacramento Municipal Util. Dist. v. Pacific Gas \& Elec. Co., 72 Cal. App. 2d 638, 644, 165 P.2d 741, 745 (3d Dist. 1946); see also H. Rogers \& A. NICHOLS, WATER FOR CALIFORNIA $\$ 314$ (1967).

10. The amicus curiae brief in support of defendants and respondents filed in the 
If a political subdivision does expand its service into the service area of a private utility by means of paralleling the existing facilities, the private utility suffers an obvious and substantial loss. Not only is it uneconomical to operate two competing utility systems within the same service area, but the public district has a nnarked competitive advantage over the regulated private utility. The latter is bound, and the former is not, by Public Utilities Commission rule 15-the so-called Mam Extension Rule. Under rule 15 a private utility must require its new customers to advance the estimated cost of installing facilities to serve them. These costs are eventually repaid under refund agreements; but the repayment may extend for as long as 25 years, the obligation is non-interest-bearing, and in fact refund agreements are commonly marketed at substantial discounts. ${ }^{11}$ Since a developer must advance the cost of water main extension to an existing private utility but not to a competing public agency, all new water service assuredly will be taken from the public district rather than from the existing private utility.

Public water agencies also have important tax advantages that are unavailable to private utilities and that enable them to charge lower rates to obtaim the aftertax income normally sought by investor-owned utility companies. Public agencies are largely exempt from property taxes, income taxes, and franchise taxes levied by the state; privately owned utility companies are not. ${ }^{12}$ Fimally, investorowned utility companies (but ordinarily not mutual water companies, to which the act also applies) are formed and operated on a profitearning basis, whereas political subdivisions are not. This basic distinction may also permit the latter to charge lower rates for providing water services than a privately owned utility that must also consider the interests of its shareholders.

Cucamonga case details prior instances of paralleling and forced sales that preceded the enactment of the legislation. Brief for California Water Ass'n as Amicus Curiae at 4-6. By reference to the Anuual Reports issued by the Public Utilities Commission, the amicus curiae brief also describes the expansion of public water service agencies that has been occurring in California for the past decades. Id. at 3-4. In 1962, the Public Utilities Commission estimated that public agencies supplied approximately 80 pereent of the water for domestic and industrial use in California. Water Main Extension Rules, 60 Cal. P.U.C. 318, 320 (1962). The public agencies, lowever, constitute less than one-third of the approximately 3,700 public and private organizations that distribute water to the public. Dep'T of Water Resources, State of California, Directory of Water Service Agencies in Califormia 1 (Bulletin No. 114 June 1962).

11. Water Main Extension Rules, 60 Cal. P.U.C. 318, 321-22 (1962). Evidence of these facts is also contained in the record in the Cucamonga case. Reporter's Transcript 836-38.

12. CaL. Const. art. 13, $\S \S 1,13 / 4,37$. See Rock Creek Water Dist. v. County of Calaveras, 29 Cal. 2d 7, 172 P.2d 863 (1946); North Kern Water Storage Dist. v. County of Kern, 179 Cal. App. 2d 268, 3 Cal. Rptr. 636 (4tlı Dist. 1960). 
Moreover, the rates charged by the private utility are based upon the assumption that the utility will retain the exclusive right to serve the area, permitting the recovery of the cost of its facilities over the life of the property; ${ }^{13}$ the duplication of its facilities invalidates this premise. Therefore, the entry of the public agency not only prevents the private utility from competing in the future but may also render the rates charged in the past too low to have provided the reasonable return to which the private utility was entitled. The private utility may have suffered a period of losses justified only by the anticipation of future growth and more profitable years; this anticipation will never be realized when a public district decides to enter the area. All expansion will be terminated, since the investunent of new capital would be imprudent in an area facing competition from another water distribution source. Moreover, the facilities of the private utility, consisting in large part of distribution lines buried in the ground and other such facilities not easily novable, will ordinarily be economically unsalvageable.

Hence, if paralleling does occur, the facilities of the existing private utility are rendered economically useless or, at least, are substantially reduced in value. Such an occurrence is not only unjust to the private investors whose property is damaged for the assumed public welfare; the possibility of such an occurrence may also serve to deter capital expansion by private utilities. ${ }^{14}$

Nonetheless, under the law as it existed prior to the 1965 legislation, such damages probably were not compensable. An argument might have been inade that the damage suffered by an existing utility whose facilities were paralleled by a public agency resulted from a "public use," so that a "taking" or "damaging" occurred under the constitutional eminent dornain provisions. ${ }^{15}$ This result was reached by the Supreme Court of Mississippi in a 1965 decision. ${ }^{16}$

13. See text accompanying note 6 supra.

14. In section 1501 [CaL. Pub. Util. Code ANN. \& 1501 (West Supp. 1972)], the legislature found and declared that

the potential loss of value of such facilities which may result from the construction and operation by a political subdivision of similar or duplicating facilities in the service area of sucl a private utility often deters such private utility from obtaining a certificate or extending its facilities to provide in many areas a water supply essential to the health and safety of the citizens thereof.

See also note 6 supra.

15. CaL. Const. art. 1, \& 14. See, e.g., Bauer v. County of Ventura, 45 Cal. 2d 276, 289 P.2d 1 (1955); Miller v. City of Palo Alto, 208 Cal. 74, 280 P. 108 (1929); cf. Associated Pipeline Co. v. Railroad Comm'n, 176 Cal. 518, 169 P. 62 (1917); Rudel v. Los Angeles County, 118 Cal. 281, 50 P. 400 (1897).

16. City of Jackson v. Creston Hills, Inc., 172 So. $2 \mathrm{~d} 215,220,58$ P.U.R.3d 128 (Miss. 1965). 
Furthermore, the general rule that there is no right to recover damages from a public body for injuries for which a private party would not be responsible ${ }^{17}$ is arguably inapplicable since only a public agency can construct duplicative facilities. ${ }^{18}$ However, the suggestion that just compensation must be paid for causing such damage undoubtedly rests too heavily "upon the naive notion that constitutional language means what it seems to say."19 Although no California case had expressly so held, the decision in Clark v. Los Angeles ${ }^{20}$ that public utility franchises are not exclusive led to the general belief that public agencies could, with impunity, construct facilities that impaired or destroyed the value of existing privately owned utility facilities. ${ }^{21}$

\section{II}

\section{The New StatuTory Scheme}

The antiparalleling statute is designed to compensate the private utility for any loss arising out of the invasion by the public entity. ${ }^{22}$ The principal operative section of the statute is section 1503:

The Legislature finds and declares that whenever a political subdivision constructs facilities to provide or extend water service, or provides or extends such service, to any service area of a private utility with the same type of service, such an act constitutes a taking of the property of the private utility for a public purpose to the extent that the private utility is injured by reason of any of its property employed in providing the water service being made moperative, reduced in value or rendered useless to the private utility for the purpose of providing water service to the service area, and such taking shall be compensable under Section 14 of Article I of the Constitution of California.

Section 1504 goes on to provide that just compensation-which is to imclude consideration of the useful value of the taken property to the political subdivision-shall be as agreed by the political subdivision and private utility or as determined by a court under the law of eminent domain. Section 1504 also provides that when the amount of compensation equals the just compensation value of all the private

17. Bauer v. County of Ventura, 45 Cal. 2d 276, 289 P.2d 1 (1955); Continuing Education of the Bar, Caltfornia Condemnation Practice 50, 177 (1960).

18. See text accompanying notes 4-5 supra.

19. Van Alstyne, Statutory Modification of Inverse Condemnation, 20 STAN. L. REv. 617 (1968).

20. 160 Cal. 30, 116 P. 722 (1911).

21. Continuing Education of the Bar, Review of Selected 1965 Code Legislation 232 (1965); cf. United Railroads v. City and County of San Francisco, 249 U.S. 517, 521 (1919); Madera Water Works v. Madera, 228 U.S. 454, 456 (1913). 1972).

22. See note 6 supra. See also CaI. Pub. Util. Code ANn. $\$ 1501$ (West Supp. 
utility's property used to distribute water in the service area, the political subdivision may acquire all such property. The basic scheme of the new legislation is thus that the public agency should pay to the private utility the amount of the reduction in the value of the private utility's property resulting from the proposed paralleling. If the value of the facilities is reduced to zero, the agency pays the entire fair market value and may receive title to the property.

Suppose the trier of fact determines that the paralleling will reduce the value of the existing facilities, but not quite to zero; may the public agency pay the difference and acquire title if it so desires? That is the situation that arose in the Cucamonga case. With respect to the property of one of the two companies involved, the jury found that damages were $\$ 244,500$-only $\$ 4,500$ less than the $\$ 249,000$ fixed as the fair market value of the property. Accordingly, the judgment directed the district to pay the amount of damages but contained no provision for transferance of title. On appeal, the district for the first time sought to obtain title to the existing facilities upon payment of the additional $\$ 4,500$. Confronted with the compelling equity of the district's position, the court of appeal strained to find a means to reach such a result. The device it employed was to interpret the jury's verdict as determining that the district's construction would render the existing system valueless, except for the "incidental salvage" value of some removable items, and this did not preclude damages and value from being regarded as equal. ${ }^{23}$

The decision of the court of appeal thus leaves open the question of how great a difference between the amount of damage and value constitutes incidental salvage, and what the rights of the public agency will be when the amount of the difference cannot possibly be regarded as incidental. The problein might have been avoided had the court selected an alternative course. If in proceedings under the new act, it is determined that damages constitute a sufficient portion of the value of the facilities that the public agency would prefer to pay the full amount of just compensation, obtain title and utilize the existing facilities rather than to pay only damages and obtam nothing tangible, the public agency could immediately file a complaint to condemn the system. Even if the agency does not wish to put the existing facilities to use, condemnation possibly may be justified to avoid payment of excessive severance damages by the agency. ${ }^{24}$ Were the agency to condemn, all questions of value would be conclusively

23. 22 Cal. App. 3d at 255-56, 99 Cal. Rptr. at 565.

24. People ex rel. Dep't of Pub. Works v. Superior Court, 68 Cal. 2d 206, 436 P.2d 342, 65 Cal. Rptr. 342 (1968). 
determined by the outcome of the prior proceedings. ${ }^{25}$ Although there would be a different valuation date in the second proceedings, it would not be unreasonable to regard the valuation establislied in the original proceedings as controlling if there was no extended delay in filing the second suit, subject only to changes arising out of the intervening destruction of facilities or the installation of betterments and improveinents. ${ }^{26}$ Perhaps an amendment to the act would be helpful to provide the public agency with this alternative without the necessity of filing a second action and to establish a deadline by which the agency must act if the valuation on the original valuation date is to be conclusive. In any event, the parties should not be concerned whether the spread between damages and value is deeined large or sinall, but the decision in Cucamonga may well make this a concern for future litigants.

III

\section{CONSTITUTIONALITY}

The court of appeal used its determination that the water district was entitled to acquire all of the Southwest properties to sidestep several of the constitutional arguments with which the district sought to invalidate the statute. In response to the contention that the payment of damages to the injured water company would constitute an unlawful gift of public funds, ${ }^{27}$ the court held the basis of the objection eliminated by the inodification of the judgenent authorizing the district to acquire title to the company's facilities. ${ }^{28}$ Similarly, because of the modification permitting the district to take the company's facilities, the court held that it did not reach the issue whether payment of damages for diminution of value unaccompanied by the transfer of title was authorized by the constitutional eminent domain provision. ${ }^{20}$

While it is therefore not possible to state that the opinion forecloses future consideration of these constitutional issues, as a practical matter the decision should be regarded as dispositive of the act's

25. 4 B. Witkin, California Procedure 3335-45 (2d ed. 1971); cf. Sutphin v. Speik, 15 Cal. 2d 195, 99 P.2d 652, reaff'd, 15 Cal. 2d 764, 101 P.2d 497 (1940); Blumenthal v. Liebman, 109 Cal. App. 2d 374, 240 P.2d 699 (1st Dist. 1952).

26. See Citizens Util. Co. v. Superior Court, 59 Cal. 2d 805, 816-17, 382 P.2d 356, 364-65, 31 Cal. Rptr. 316, 324-25 (1963); text accompanying note 92 infra. If there is an extended delay between the filing of the complaint and the trial in the initial action, the valuation date in those proceedings will have been advanced, so that the adjudicated value will reflect appreciation or depreciation that occurred snbsequent to the commencement of the proceedings under section 1503. See text accompanying note 89 infra.

27. CAL. ConsT. art. XIII, $\S 25$.

28. 22 Cal. App. 3d at 259, 99 Cal. Rptr. at 568.

29. CaI. Const. art. I, § 14; see 22 Cal. App. 3d at 260, 99 Cal. Rptr. at 568. 
validity. In the first place, the court was incorrect in its assertion that these issues were not before it: The court assumed that upon remand the water district would elect to pay the difference between damages and fair market value in order to acquire title to Southwest's property. However, should the district choose not to expend those additional funds, it would remain obligated to pay the damages without acquiring title to the facilities. At a minimum, the modified judgment confronts the district with this choice, which ordinarily would be sufficient to support the justiciability of a challenge to the alternatives before it. $^{30}$

The court's opinion must also be read with an eye upon the strength of the district's contentions. Neither argument that the court avoided is compelling. In urging that payment of damages would constitute a constitutionally proscribed gift, the district cited only cases overturning statutes authorizing compensation for injuries that had occurred prior to the enactment of the legislation. ${ }^{31}$ But it is plain that the prospective imposition of liability upon a public agency does not constitute a gift of public funds. ${ }^{32}$ "[I]f the expenditures . . . [are] inade to serve a proper public purpose, they ... [are] not a 'gift' despite the fact that soine private persons may have received special benefits." ${ }^{33}$

In Patrick v. Riley, ${ }^{34}$ the suprene court upheld the validity of a statute providing for coinpensation to owners of tubercular cattle that were slaughtered by the state. The court acknowledged that such compensation was not constitutionally required but found that such payment could reasonably be regarded as serving a public purpose by obviating resistance of cattle owners to immediate enforceinent of the legislation; therefore, it was not a gift of public funds. In Dittus v. Cranston, ${ }^{35}$ a closely analogous case, the suprene court found that reinburseinent by the state for fishing equipinent rendered valueless by a statute prohibiting certain fishing could have been regarded by the legislature as pronoting the fish-protection laws by taking illegal equipment out of circulation, encouraging fishing in other parts of the state, and permitting enforcennent persounel to work

30. Cf. Fort v. Civil Service Comm'n, 61 Cal. 2d 331, 334, 392 P.2d 385, 387, 38 Cal. Rptr. 625, 627 (1964).

31. The cited cases were County of Alameda v. Chambers, 35 Cal. App. 537, 170 P. 650 (3d Dist. 1917); Molineux v. State, 109 Cal. 378, 42 P. 34 (1895); Bourn v. Hart, 93 Cal. 321, 28 P. 951 (1892).

32. E.g., Higgins v. Santa Monica, 62 Cal. 2d 24, 396 P.2d 41, 41 Cal. Rptr. 9 (1964); Flournoy v. State, 230 Cal. App. 2d 520, 41 Cal. Rptr. 190 (3d Dist. 1964).

33. Wine v. Boyer, 220 Cal. App. 2d 375, 379, 33 Cal. Rptr. 787, 790 (2d Dist. 1963).

34. 209 Cal. $350,355-57,287$ P. 455, 457-58 (1930).

35. 53 Cal. 2d 284, 287, 347 P.2d 671, 673, 1 Cal. Rptr. 327, 329 (1959). 
elsewhere. Therefore, the court held that such compensation was not a gift of public funds. The attorney general has also issued an emphatic opinion upholding analogous legislation to compensate occupants of park lands whose permits are revoked because of proposed highway construction. ${ }^{36}$ Therefore, in view of the preeminently proper public purposes that the antiparalleling statute was designed to serve, it is difficult to perceive how the court of appeal could have been troubled by this contention in Cucamonga.

The same must be said of the argument that the eminent domain provision does not authorize compensation for the reduction in value arising out of the construction of parallel facilities. Sections 1503 and 1504 direct that the procedures applicable in eminent domain proceedings be utilized to determine the amount of compensable loss payable under the statute. That, however, does not make the validity of the statute depend upon whether such compensation would otherwise be required by the eminent domaim provisions. Elsewhere in its opinion, the court of appeal expressly recognized that the statute need not be upheld by reference to a constitutional provision authorizing such legislation, but survives attack so long as the constitution does not prohibit it. ${ }^{37}$ Article I, section 14 does not limit the circumstances under which the legislature may provide for compensation. ${ }^{38}$ The language of section 1501 makes plaim that the legislature deemed the statute "necessary for the public health, safety, and welfare;"39 given its background, ${ }^{40}$ this is more than enough to uphold the legislation in the absence of some other constitutional interdiction. ${ }^{41}$

In Cucamonga, the court did expressly reject assertions that several constitutional provisions prohibited the legislation. The provision of the California constitution authorizing municipal corporations to operate public works ${ }^{42}$ was found not to be inimical to the legislature's provision for compensation under the new act. ${ }^{43}$ The equal

36. 38 Op. CAL. AtT'y GeN. 134 (1961).

37. 22 Cal. App. 3d at 257, 99 Cal. Rptr. at 566.

38. E.g., Patrick v. Riley, 209 Cal. 350, 355-57, 287 P. 455, 457-58 (1930); Dittus v. Cranston, 53 Cal. 2d 284, 287, 347 P.2d 671, 673, 1 Cal. Rptr. 327, 329 (1959); 38 Op. CAL. ATT'y GeN. 134, 135-36 (1961).

39. Cat. Pub. UtIL. Code Ann. \& 1501 (West Supp. 1972).

40. See text accompanying notes 3-21 supra.

41. E.g., Ex parte Hadacheck, 165 Cal. 416, 419, 132 P. 584, 585, affd sub. nom Hadacheck v. Sebastian, 239 U.S. 394 (1913).

42. CAL. CONST. art. XI, $\$ 9$.

43. 22 Cal. App. 3d at 257-58, 99 Cal. Rptr. at 566-67. See, e.g., Los Angeles v. Los Angeles Gas \& Elec. Corp., 251 U.S. 32, 38 (1919); Davoust v. City of Alameda, 149 Cal. 69, 84 P. 760 (1906); Glenbrook Dev. Co. v. City of Brea, 253 Cal. App. 2d 267, 61 Cal. Rptr. 189 (4th Dist. 1967). 
protection clauses of the United States and California constitutions ${ }^{41}$ were held not to invalidate the limitation of the statute's coverage to water services, rather than to all public service facilities. ${ }^{45}$ And the statute was held not to run afoul of the recently repealed provision of the state constitution prohibiting the delegation to private corporations of the power to control or interfere with municipal improvement. $^{46}$

Thus, while the opinion in Cucamonga may not foreclose further challenges to the validity of the antiparalleling statute, there is little basis to suppose that the act will not be upheld, regardless of the verdict on damages and fair market value.

\section{IV}

\section{When Just Compensation Must Be Paid}

In the normal eminent doinain situation there is little problem determining when the condemnation action nust be commenced. If the condemning agency seeks to acquire the property, the agency inust institute the proceedings to obtain title before it can acquire the right to possession. Ordinarily, title will not pass until after the entry of judgment and the payment into court of the judgment amount. ${ }^{47}$ There are provisions permitting the entry of an interlocutory order in certain cases granting immediate possession to the condemning agency before the determination of the amount of just compensation, ${ }^{48}$ but this procedure too requires that the eminent domam action at least be commenced and security deposited before possession is obtained.

When a public agency plans a course of action not requiring that it take possession but which will nonetheless cause coinpensable damage to an individual's property, payment must also be inade to the property owner before the agency is entitled to perform the acts causing such dainage. Article I, section 14 expressly requires that "private property shall not be taken or damaged for public use without just compensation having first been made to, or paid into court for,

44. U. S. Const. amend. XIV; CAL. CoNST. art. I, $\S 111,21$; id. art. IV, $\$ 16$.

45. 22 Cal. App. 3d at 258-59, 99 Cal. Rptr. at 567-68. The water district also advanced several other bases of allegedly improper classification, all of which were passed over without comment. at 569 .

46. Former CAL. Const. art. XI, $\$ 13.22$ Cal. App. 3d at 260, 99 Cal. Rptr.

47. Cal. Code Civ. Pro. $\$ 1253$ (West 1970).

48. Cal. Const. art. I, $\S 14$; CaL. Code Civ. Pro. $\$ \S 1243.4-43.5$ (West 1970). There is also a procedure by which the condemining agency may obtain possession pending appeal. Id. $\$ 1254$. 
the owner. ..."49 Thus, the California courts have consistently upheld the property owner's right to enjoin public agencies from taking action that will cause damage to private property until such time as payment is first inade to or into court for the owner. ${ }^{50}$ If the property owner fails to make timely application for an injunction, his recourse is then an action for inverse condemnation, but the right to recover in inverse condemnation proceedings is not a substitute for the right to receive prior payment and to enforce this right by injunction. ${ }^{61}$

The situation is more complex when a public water agency proposes to parallel existing private utility facilities. There is no physical damage to the property of the private water company. The impact upon the private utility is solely economic, so that is it impossible to define any single act or point in time at which the damage occurs. In the normal course of events, a public district may be formed, if not preexisting, or if already existing, it may annex the area within which it proposes to extend service. Thereafter, the proposed improvements inust be designed. The inethod of financing must be determined, and if by assessment, there must be compliance with the formalities prescribed by the applicable municipal improvement act. ${ }^{62}$ At some point, the governing board of the political subdivision inust adopt a resolution authorizing the proposed construction. The agency ordinarily will approach construction by advertising for competitive bids and by awarding one or more contracts for the construction of the proposed facilities. Thereafter, construction will be undertaken, eventually completed, and ultimately the public agency will begin furnishing water service to the service area. Its custoiners may initially be only the new residents of the area, but, eventually, the existing customers of the private utility can be expected to be acquired by the public agency. ${ }^{53}$ Ultimately, the private utility

49. CAL. Const. art. I, $\$ 14$ (emphasis added).

50. E.g., Willcox v. Engebretsen, 160 Cal. 288, 299, 116 P. 750, 754 (1911); see also Beals v. City of Los Angeles, 23 Cal. 2d 381, 387, 144 P.2d 839, 843 (1943); Geurkink v. City of Petaluma, 112 Cal. 306, 310, 44 P. 570, 571 (1896); Bigelow v. Ballerino, 111 Cal. 559, 561, 44 P. 307, 308 (1896); Frustruck v. City of Fairfax, 212 Cal. App. 2d 345, 370, 28 Cal. Rptr. 357, 372 (1st Dist. 1963); Annot., 133 A.L.R. 11, 45-68 (1941), supplemented, 93 A.L.R.2d 465-74 (1964).

51. See Heimann v. Los Angeles, 30 Cal. 2d 746, 185 P.2d 597 (1947); People v. Ricciardi, 23 Cal. 2d 390, 144 P.2d 799 (1943); Silva v. San Francisco, 87 Cal. App. 2d 784, 198 P.2d 78 (1st Dist. 1948).

52. CAL. STS. \& H’waYs Code ANN. $\$ 5000$ et seq. (West 1969); id. $\$ 8500$ et seq.; id. $\$ \S 10000$ et seq.; id. $\$ \$ 35400$ et seq.; see generally 2 H. RoGERs \& A. NichoLs, supra note 9, part IV.

53. This shift appears probable for several reasons: The public district will install a new system, and the private utility will be unwilling to invest more capital in a losing proposition. Costs will inevitably increase over time, and since the private utility cannot compete for new customers, its per unit costs will increase rather 
can be expected to abandon the area and discontinue service within it.

At what point, then, is the political subdivision required to pay compensation to the private utility? At one extreme it might be suggested that initial steps, such as annexation of the area within which the facilities are to be constructed, constitute the first stage in the process leading to the injury and therefore that damages must be paid at that point. However, at this early stage the contingencies are very great. The possibility that the agency may not in fact proceed to construction is sufficiently substantial that payment to the private utility would be premature. More iniportant, until the proposed facilities are at least designed, it is inipossible to determine the extent of the impact upon the existing facilities.

The funding stage would also be a possible point at which to require payment, but here, too, substantial contingencies remain; moreover, section 526(a) of the Code of Civil Procedure ${ }^{54}$ provides that no injunction shall be granted restraining the offering, sale, or issuance of any municipal bond, so there is probably no effective means of preventing a political subdivision from proceeding to obtain financing, whether or not it has made provisions for payment to the private utility.

At the other extreme, it seems clear that the private utility can demand compensation before the new systein of the political subdivision has been coinpleted and customers have begun to shift. While it may be true that damages are imperceptible until completion of the public project (though not entirely lacking, since the prospect of service by the public agency may affect the conduct of prospective private utility customers), the constitution requires that payment be made prior to the damaging of the private property.

The point im time at which damages must be paid to the private utility seems appropriately determined by a literal application of the language of the antiparalleling statute. Section 1503 speaks of "construction" of facilities by the political subdivision, and the point of construction does indeed seem a reasonable point at which to require payment. By this time, the possibility of abandonment by the public district is remote and the system has been designed, so it is possible to evaluate the likely effect of the proposed new facilities upon the existing private facilities. As a practical matter, the public

than decrease. The most likely occurrence is thus that the private utility will be forced to surrender its certificate of public convenience and necessity and to discontinue service in the area.

54. Cal. Code Civ. Pro. $\$ 526($ a) (West 1970). 
agency may wish to obtain a determination of the alnount of compensation it must pay prior to awarding a contract for the construction of the parallel facilities. If the ainount of compensation cannot quickly be agreed upon, the time required for trial may prevent the contractor from proceeding until many months after the contract has been awarded, by which time costs may have increased and renegotiation of the contract may be necessary. Moreover, if the amount of damages is substantially greater than anticipated by the agency, it may wish to reconsider the design of its project and should be able to do so without mcurring liabilities for the breach of its obligations to the contractor. In any event, if a public agency attempts to commence construction of facilities that will duplicate existing private utility facilities without making provision for payment to the utility, injunctive relief should be available to lialt construction until the conclusion of proceedings determining the amount of compensation to be paid to the private utility. ${ }^{55}$

\section{V}

\section{Proceedings Under the Statute}

Although there is little basis to doubt the validity of the antiparalleling legislation or the right to imvoke the act before duplicative construction may be undertaken, the statute is nonetheless plagued with questions of interpretation and application.

\section{A. The Right to Compensation}

The langnage of section 1503 is somewhat difficult to come to grips with. ${ }^{56}$ The statute provides that if a public agency constructs parallel facilities there is a "taking," but only to the extent that, in effect, the existing facilities of the private utility are damaged. Thus, the statute equates the fact of damage with the amount of dainage. In part, this may be unavoidable, since the two are obviously inter-

55. Thus, in Southwest Water Company v. Cucamonga County Water Dist. [No. CW-1890 (Cal. Super. Ct., San Bernardino County, Oct. 19, 1966)], in which the county water district had received bids and had indicated its intent to proceed with construction without first making payment to the existing private water companies, the superior court entered a preliminary imjunction prohibiting the water district

frown undertaking, ordering or causing to be undertaken construction of improvements or facilities described in [a specified resolution] until such time as the defendants shall have paid to plaintiff, or paid to the court for the benefit of plaintiff, or posted a bond in a form and amount to be agreed upon by the parties or, if they fail to agree, to be set by order of the Court upou further hearing.

Subsequent to the entry of this order, the district commenced the proceedings leading to the appeal discussed earlier in the text.

56. Section 1503 is reproduced in the text accompanying note 22 supra. 
related. If there is no reduction in value to the property of the private utility, there is no damage and thus no right to compensation. If construction of parallel facilities does reduce the utility of existing facilities, the amount of damage will depend upon the extent to which the facilities retain some usefulness after the completion of the new facilities.

If the procedure under the new statute is to follow the normal eminent domain format, as directed by section 1504, the right to compensation (that is, the fact of damage) inust be determined by the court, whereas only the amount of compensation is for determination by the jury. ${ }^{57}$ Hence, if the political subdivision does not stipulate that its proposed construction will, to some extent, render the existing facilities inoperative, reduced in value, or useless for the purpose of providing water service to the service area, this issue will require prior determination by the court. Once it has been determined by the court that such damage will result from the proposed construction, the amount of the damage is to be submitted to the jury for its determination.

A related verbal perplexity arises froin the three criteria: "made inoperative, reduced in value or rendered useless to the private utility for the purpose of providing water service to the service area." As noted, these criteria define both the circumstances under which there is a right to the payment of compensation and the amount of compensation to which the private utility is entitled. What is far from clear, lowever, is whether the three criteria are distinct or simply repetitious. Regarding the term "inoperative" as limited to physical moperability would distinguish the first phrase from the latter two, both of which certainly encompass reduction in economic value. However, if a political subdivision were to physically obstruct a water company's facilities, such conduct would be coinpensable under normal eminent domam provisions, and there is no evidence that the statute was intended simply to confirm preexisting rights.

Probably the soundest conclusion is that the three criteria are largely redundant. The statute means that if, as a result of the construction of duplicative facilities in a service area, it becomes either physically impossible or less economically rewarding to operate the existing facilities, there is dainage to the property of the private water company. The amount of the dannage is the amount by which the value of the facilities will be reduced as a result of the construction of the new facilities.

57. People v. Wasserman, 240 Cal. App. 2d 716, 728, 50 Cal. Rptr. 95, 102-03 (1st Dist. 1966). 


\section{B. Property Protected}

Another possible uncertainty under the statute concerns the types of property that are to be considered in determining damages. Section 1501, which sets forth the legislative findings and declarations, speaks of the potential loss of value of the "facilities" of the private utility. The reference to "facilities" might be read to suggest that only such tangible items as pipelines, meters, and reservoirs may be considered. Among other things that such a narrow reading would exclude are easeinents, water rights, and intangibles. ${ }^{58}$

It is doubtful that any court would seriously entertain such a restricted reading of the act. Sections 1503 and 1504, the operative provisions, speak more broadly of the "property" of the private utility that is reduced in value by reason of the parallel construction. There is no doubt that both water rights and real property rights fall within the broader term "property," and there is no reason why these should be treated differently under the statute from other properties of the utility that are used to furnish water service. Neither water rights nor easements can be condemned without the payment of just compensation. $^{59}$ The expanded right to acquire title to the damaged property conferred upon the public agency in Cucamonga makes it even more essential that all components that would be included in a normal condemnation action be included in the determination of fair market value under the antiparalleling statute.

The somewhat more troublesome question of whether intangibles should be included in determining just compensation under the new statute is more conveniently treated as a question of valuation, discussed in the following section.

\section{Valuation}

The procedures and standards for determining compensation under the new legislation appear in section 1504. This section pro-

58. This interpretation was in fact urged by the water district in the Cucamonga case, but not until appeal. Relying in part upon the doctrine of invited error and in part upon instructions given by the trial court that were not entirely inconsistent with the position raised by the district on appeal, the court of appeal avoided a definitive holding on the scope of the statute in this respect. 22 Cal. App. 3d at 261, 99 Cal. Rptr. at 569.

59. McCardle v. Indianapolis Water Co., 272 U.S. 400, 413 (1926); San Joaquin \& Kings River Canal \& Irrig. Co. v. County of Stanislaus, 233 U.S. 454, 459 (1914); East Bay Water Co. v. McLaughlin, 24 F. Supp. 222, 226 (N.D. Cal. 1938); County of Los Angeles v. Wright, 107 Cal. App. 2d 235, 241, 236 P.2d 892, 879 (2d Dist. 1951); City of Los Angeles v. Geiger, 94 Cal. App. 2d 180, 195, 210 P.2d 717, 727 (2d Dist. 1949); People v. Buellton Dev. Co., 58 Cal. App. 2d 178, 183, 136 P.2d 793, 795 (2d Dist. 1943); Monterey Peninsula Municipal Water Dist., 63 Cal. P.U.C. 533, 544-45 (1964). 
vides that "just compensation for the property . . . taken . . . shall be ... as ascertained and fixed by a court of competent jurisdiction pursuant to the laws of this State relating to eminent domain." The incorporation of this body of law on eminent domain undoubtedly was intended to provide some measure of certainty to proceedings under the new statute. ${ }^{60}$ But the task of utility valuation-difficult under any circumstances ${ }^{61}$-is beset with additional problems when conducted purusant to the antiparalleling act.

At the outset, section 1504 contains a basic anbiguity. There is not, in California, a simgle set of laws relating to the condemnation of utility property, but two such sets. The standard provisions of the California Code of Civil Procedure and Evidence Code that govern eminent domain provisions in superior court ${ }^{62}$ may be used to condemn the property of a private utility. ${ }^{63}$ But there is also a set of provisions in the Public Utilities Code by which the Public Utilities Commission is authorized to determine the value of utility property that a public agency seeks to condemn. The rules and procedures developed by the commission do not entirely correspond to the rules developed for proceedings in the superior court. ${ }^{64}$ While it may be possible to infer from section 1504's direction that a "court of coinpetent jurisdiction" should determine value so that only the standards applicable in superior courts should apply, the grant of jurisdiction to the courts does not necessarily exclude the standards of the Public Utilities Commission from the "laws of this State relating to eminent domain," which govern the determination of value under the act. Because of the special characteristics of utilities and their valuation, deviations from the standard superior court procedures are unavoidable, even in outright condemnation proceedings. ${ }^{65}$ Certainly no greater adherence to the nornal rules of valuation should be insisted upon when the proceedings are brought under the antiparalleling statute.

There are at least two fundainental reasons for which the valuation of utility property necessarily proceeds along somewhat different

60. See Continuing Education of the Bar, supra note 21, at 233.

61. See generally sources cited notes 66-68 infra; 2 L. ORger, Valuation UNDER THE LAW OF EMINENT DOMAIN 1-147 (2d ed. 1953).

62. Cal. Code Civ. Pro. $\S \S 1237-72.09$ (West 1970); CaL. Evid. Code $\S \S 810-22$ (West 1968).

63. Cal. Code CTv. Pro. $\$ 1238(3)$ (West 1970); see Citizens Util. Co. v. Superior Court 59 Cal. 2d 805, 382 P.2d 356, 31 Cal. Rptr. 316 (1963).

64. Cat. Const. art. XII, $\S 23 a$; Cal. Pub. Util. Code ANN. $\S \S 1401-14$ (West 1956).

65. See Citizens Util. Co. v. Superior Court, 59 Cal. 2d 805, 382, P.2d 356, 31 Cal. Rptr. 316 (1963); City of North Sacramento v. Citizens Util. Co., 218 Cal. App. 2d 178, 188, 32 Cal. Rptr. 308, 314 (3d Dist. 1963). 
lines than the valuation of most parcels of improved realty. There is ordinarily an absence of sales of comparable property, so that there usually exists no market within which to gauge a true market value. ${ }^{66}$ And, unlike the normal situation, the condemnor ordinarily does acquire the business of the utility in addition to its property. ${ }^{67}$ Thus, of necessity, the measure of value in utility condemnation is extremely general. ${ }^{68}$ All factors that may reasonably be thought to affect the value of the property are given consideration. The cost of reproducing the physical facilities less accrued depreciation is highly significant, ${ }^{69}$ but original costs, ${ }^{70}$ capitalized earnings, ${ }^{71}$ probable future revenues, ${ }^{72}$ and much more ${ }^{73}$ are also considered.

The most significant respect in which the normal valuation rules differ from those that apply to utilities is in the treatment of lost profits and intangibles, such as going-concern value and organization expense. Evidence Code section 819 has codified the normal rule that the capitalized value of mcome or profits attributable to a busimess conducted on the condemned property may not be considered in

66. Citizens Util. Co. v. Superior Court, 59 Cal. 2d 805, 817, 382 P.2d 356, 364, 31 Cal. Rptr. 316, 324 (1963); City of Fresno, 40 Cal. R.R. Comm'n 204, 207 (1936); City of Baxter Springs v. Folshay Co., 110 Kan. 409, 412-13, 204 P. 678, 679 (1922). Cf. City of Pleasant Hill v. First Baptist Church, 1 Cal. App. 3d 384, 397 n.1, 82 Cal. Rptr. 1, 7-8 n.1 (1st Dist. 1969).

67. City of Phoenix v. Consolidated Water Co., 101 Ariz. 43, 45, 415 P.2d 866, 868 (1966), Onondaga County Water Auth. v. New York Water Service Corp., 285 App. Div. 655, 661, 139 N.Y.S.2d 755, 762 (1955).

68. See City of Fresno, 40 Cal. R.R. Comm'n 204 (1936); City of Baxter Springs v. Folshay Co., 110 Kan. 409, 204 P. 678 (1922); 2 L. OrgeL, supra note 61 , at $65-66$ (2d ed. 1953 ).

69. See Wichita Water Co. v. City of Wichita, 271 F. 973, 975-76 (D. Kan. 1921); Joint Highway Dist. No. 9 v. Ocean Shore R.R., 128 Cal. App. 743, 756-57, 18 P.2d 413, 419 (1st Dist. 1933); City of Redding, 39 Cal. R.R. Comm'n 193, 194 (1934); Monterey Peninsula Municipal Water Dist., 63 Cal. P.U.C. 533, 537 (1964); 27 AM. JuR. Eminent Domain \$ 339, at 172 (1966); Continuing Education of THE BAR, supra note 17, § 3.16; cf. City of Pleasant Hill v. First Baptist Church, 1 Cal. App. 3d 384, 82 Cal. Rptr. 1 (1st Dist. 1969).

70. The original cost may be relevant, but ordinarily is entitled to little weight. See City of Phoenix v. Consolidated Water Co., 101 Ariz. 43, 47, 415 P.2d 866, 870 (1966); City of Redding, 19 Cal. R.R. Comm'n 267, 271-72 (1921); Onondaga County Water Auth. v. New York Water Serv. Corp., 285 App. Div. 655, 662, 139 N.Y.S.2d 755, 763 (1955); cf. CAI. Evid. CoDE § 815 (West 1968).

71. See City of Fresno, 40 Cal. R.R. Comm'n 204 (1936); Monterey Peninsula Municipal Water Dist., 63 Cal. P.U.C. 533 (1964).

72. See United States v. Brooklyn Union Gas Co., 168 F.2d 391, 395-96 (2d Cir. 1948); City of Phoenix v. Consolidated Water Co., 101 Ariz. 43, 48, 415 P.2d 866, 871; Sacrainento Municipal Util. Dist., 44 Cal. R.R. Comm'n 467, 478 (1942); City of Fresno, 40 Cal. R.R. Comm'n 204, 215 (1936).

73. See City of Fresno, 40 Cal. R.R. Comm'n 204 (1936); City of Baxter Springs v. Folshay Co., 110 Kan. 409, 204 P. 678 (1922); 2 L. ORGEL, supra note 61, at 81-181. 
determining the value of the property. ${ }^{74}$ And loss of business is not an element that may be considered in determining severance damages. ${ }^{75}$ These limitations, however, do not apply when valuing a utility. Because the condemnor acquires and will carry on the busmess of the utility, consideration of capitalized earnings is appropriate and accepted. ${ }^{78}$ The element of uncertainty and speculation normally feared in such an approach, ${ }^{77}$ though not entirely lacking, ${ }^{78}$ is far less than when the very nature of the business is subject to change and revenues are subject to swings that do not confront utility operations. Indeed, when the capitalization approach is followed, projected future earnings of the utility may be capitalized, so long as the projections are shown to be reasonably probable. ${ }^{79}$

In proceedings before the Public Utilities Commission, there is an alternative approach that is also accepted to give recognition to the value attached to a going business over and above the replacement value of its physical properties. That is to include an estimate of the expense of organizing and commencing the utility's business and an amount representing the going-concern value of the utility. ${ }^{80}$

In Cucamonga, the trial court instructed the jury that injury to a business was not a compensable element of damage, and this imstruction was noted by the court of appeal, seemingly with approval. ${ }^{81}$ Though not indicated in the opinion, the trial court also excluded prof-

74. Car. Evid. Code $₹ 819$ (West 1968); see People ex rel. Dep't of Public Works v. Dunn, 46 Cal. $2 \AA$ 639, 641, 297 P.2d 964, 966 (1956). See also ConTINUING EDUCATION OF THE BAR, supra note 17, § 3.13.

75. People ex rel. Dep't of Public Works v. Ayon, 54 Cal. 2d 217, 226, 352 P.2d 519, 524, 5 Cal. Rptr. 151, 156 (1960); City of Oakland v. Pacific Coast Lumber \& Mill Co., 171 Cal. 392, 398, 153 P. 705, 707 (1915).

76. 2 L. ORGEL, supra note 61 , at $58-59,148$. See case cited note 71 , supra; Southern Cal. Edison Co. v. Railroad Comm'n, 6 Cal. 2d 737, 750-51, 59 P.2d 808, 814 (1936); Aldercroft Heights County Water Dist., 64 Cal. P.U.C. 429 (1965); Sacramento Municipal Util. Dist., 44 Cal. R.R. Comm'n 467, 479-89 (1942).

77. People ex rel. Dep't of Public Works v. Dunn, 46 Cal. 2d 639, 297 P.2d 964 (1956).

78. See City of Los Angeles, 37 Cal. R.R. Comm'n 117, 118-19 (1932); City and County of San Francisco, 33 Cal. R.R. Comm'n 202, 204-06 (1929).

79. See cases cited note 64 supra.

80. Monterey Peninsula Municipal Water Dist., 63 Cal. P.U.C. 533, 537 (1964); East Bay Water Co. v. McLaughlin, 24 F. Supp. 222, 227 (N.D. Cal. 1938); City of Fresno, 40 Cal. R.R. Comm'n 204, 215-16 (1936); City and County of San Francisco, 33 Cal. R.R. Comm'n 202, 208, 231-33 (1929); City of Los Angeles, 32 Cal. R.R. Comm'n 579, 587-89 (1929). This going concern value is generally recognized in other jurisdictions as well. See City of Thibodaux v. Louisiana Light \& Power Co., 225 F. Supp. 657, 666-67 (E.D. La. 1963); City of Phoenix v. Consolidated Water Co., 101 Ariz. 43, 45, 415 P.2d 866, 868 (1966); Kennebec Water Dist. v. City of Waterville, 97 Me. 185, 206, 54 A. 6, 19 (1902).

81. 22 Cal. App. 3d at 264, 99 Cal. Rptr. at 571. 
fered evidence of going-concern value and organization expense. ${ }^{82}$ In refusing to adopt the standards applied in utility condemnation cases, the trial court seems to have been influenced by the view that the water district probably would not acquire title to the property as a result of the proceedings. Whatever weight this consideration may have been entitled to receive when the case was tried, the premise upon which it was based was removed by the appellate decision expanding the agency's right to acquire title by paying the difference between damages and fair market value. To the extent that the utility does possess value as a going operational entity, the reduction in that value by reason of service duplication may be substantial even if the public agency chooses not to acquire title to the physical properties. But since the agency may well have the option to acquire title and therefore the benefit of the operating intangibles, there is no reason these should not be taken into account in determining both total value and the amount of damage sustamed by reason of the duplication. Indeed, the cryptic direction in section 1504 that the ascertainment of just compensation include "consideration of the useful value to the political subdivision of the property so taken"-a departure froin elementary principles of valuation in eminent domain proceedings ${ }^{83}$ - can most sensibly be regarded as a legislative determination that the incomegenerating capability of the property should be considered in proceedings under the statute.

Another possible justification for departing from the rule that applies in utility condemnation cases may exist if the paralleled facilities constitute only a small portion of the utility system. In such a case, the intangibles that attach to an operational system as a whole may be lacking with respect to only a segment. But if this rationale were accepted, a utility suffering successive partial duplications might never be entitled to recover for the loss of these intangible values which would have been recoverable had the system been valued as a whole. Rather than exclude the intangibles from consideration, it wonld be fairer to leave to the expert witnesses the admittedly difficult task of allocating such values to the portion of the system for which compensation is being calculated.

There are other matters besides the treatment of profits and intangibles where some flexibility is required in applying the nornal superior court eminent domain procedures to utility valuation under the antiparalleling statute. The proscription contained in Evidence

82. Reporter's Transcript 607, 750-51, 1267-73.

83. Temescal Water Co. v. Marvin, $121 \mathrm{Cal}$. App. 512, 518-19, 9 P.2d 335, 337 (4th Dist. 1932). 
Code section $822(a)^{84}$ against an expert's basing an opinion of value upon comparable sales to agencies possessing the power of eminent domain is far more limiting in the case of utility property than in the case of most parcels of realty. The restriction almost inevitably will exclude froin consideration what few sales might otherwise be helpful in establishing the value of utility property. Sales of water rights occur with sufficient frequency to provide a meaningful market for what may be one of the more valuable holdings of a private utility, but almost all such sales are made either to government agencies or to private utilities that have the power of eminent domain. Such sales may be given consideration in proceedings before the Public Utilities Commission but would be excluded from consideration by strict adherence to the terms of section 822(a). There is no evidence that the legislature consciously intended to create this paradox in adopting the new Evidence Code. Similarly, undeviating adherence to the rule that land and improvements cannot be valued separately ${ }^{85}$ may preclude use of the most appropriate means of appraising such diverse items of utility property as distribution plant, water rights, and real property rights. A party may wish to call several expert witnesses to testify to the value of different componcnts of the system, as is commonly done in proceedings before the Public Utilities Commission. This would be particularly appropriate in the absence of coinparable sales by which to gauge the market value of the systern as a whole. ${ }^{86}$ Certainly section 1504 should not be regarded as precluding such a procedure.

Construing section 1504 to permit the court to draw selectively upon the procedures evolved botll by the courts and by the Public Utilities Commission admittedly will produce some uncertainty. Moreover, a superior court jury undoubtedly lacks the sophistication of the Public Utilities Commission to evaluate the additional testimony customarily received in proceedings before the commission. But uncertainty is always the price of sensible flexibility. And observance of the rule limiting evidence of value to the opinions of expert witnesses, ${ }^{87}$ while permitting the expert to support his opinion by reference to facts properly considered under the broader PUC standards, should enable the jury to act as imtelligently as in other areas im which it is required to make complex determinations.

84. CAL. Evid. CoDe $\$ 822$ (a) (West 1968).

85. People v. Ocean Shore R.R., 32 Cal. 2d 406, 427-28, 196 P.2d 570, 584 (1948); San Bernardino County Flood Control Dist. v. Sweet, 255 Cal. App. 2d 889, 899-900, 63 Cal. Rptr. 640, 646-47 (4th Dist. 1967); Imperial Irrig. Dist. v. Hamerson, 86 Cal. App. 2d 904, 906, 195 P.2d 542, 543 (4th Dist. 1948).

86. See 2 L. ORGRL, supra note 61, at 78-80.

87. Cal. Evid. Code $\S 813$ (West 1968). 


\section{Valuation Date}

As in all other condemnation proceedings, the valuation date is, in the first instance, the date on which the summons is issued. ${ }^{88}$ If the case does not proceed to trial within 1 year, the date on which trial commences will control if Code of Civil Procedure section 1249 applies; but if the Public Utilities Code provisions governing proceedings before the PUC apply, the valuation date is far less certain..$^{89}$ Since the proceedings are in the superior court-and secondarily because the Code of Civil Procedure rule is far clearer-the procedure established by the Code of Civil Procedure should control this issue.

Although the duplicative construction ordinarily will not have occurred when the complaint is filed, both the value of the existing facilities and the reduction in their value in light of the service duplication must be determined as of the valuation date. Any other alternative-such as determining the amount of damages as of the estimated date on which the parallel construction will be completedwould inject undesirable uncertainty into the proceedings; it would create the possibility of suppleinental proceedings if there were a deviation from the estimated schedule; and, in any event, it would be contrary to the express provision in section 1249 that "the basis of damages to property not actually taken but injuriously affected" shall be the date of issuance of the summons. ${ }^{90}$ This rule has been interpreted to mean that severance damages must be based on the premise that the improvement is completed..$^{91}$

Section 1249 also expressly provides that no compensation shall be paid for the value of improvennents added to the property subsequent to service of the summons. A public utility, however, is compelled to make such repairs and extensions to its systein as is necessary to provide service in its service area. ${ }^{92}$ Therefore, despite the

88. Cal. Code Ctv. Pro. $\$ 1249$ (West 1970); cf. Cal. Pub. Util. Code ANn. $\S 1411$ (West 1956).

89. See City of Riverside, No. A 49307 (Cal. P.U.C., Aug. 4, 1970) (decision No. 77583 ).

90. Cal. Code Crv. Pro. § 1249 (West 1970).

91. People ex rel. Dep't of Public Works v. Schultz Co., 123 Cal. App. 2d 925, 933, 268 P.2d 117, 123 (1st Dist. 1954). See also, Pierpont Inn, Inc. v. State, 70 Cal. 2d 282, 293, 449 P.2d 737, 744-45, 74 Cal. Rptr. 528-29 (1969).

In Cucamonga, the jury was instructed, in part, that

in determining just coinpensation you must consider the inarket value of the property involved herein and danages which will accrue to each of the defendant's property by reason of plaintiff's construction as proposed as of the date of valuation here which is [the date on which the district's complaint was filed].

Clerk's Transcript 383.

92. Cal. PUb. UTIL. CODE ANN. $\$ 451$ (West 1956); see Citizens Util. Co. v. Superior Court, 59 Cal. 2d 805, 811, 382 P.2d 356, 361, 31 Cal. Rptr. 316, 321 (1963). 
unqualified language of section 1249 , in an outright condemnation of a privately owned utility compensation must be paid for improvements necessarily installed between the dates of valuation and transfer of title. ${ }^{93}$ Here the courts have looked by way of analogy to the twostage procedure customarily followed before the Public Utilities Commission, ${ }^{94}$ recognizing that failure to coinpensate for improvements added under legal compulsion would run afoul of constitutional restrictions. ${ }^{95}$ For the same reason, if a public agency proceeding under the antiparalleling statute should acquire title to the property of a privately owned public utility, ${ }^{96}$ the utility undoubtedly will also be entitled to recover for betterments installed subsequent to the initial valuation date if installed in performance of obligations imposed by its certificate of public convenience and necessity. In principle the private utility should also be entitled to compensation for damage to improvennents necessarily added after commencenient of the suit, even if title is not acquired by the public agency, but this may push the principle beyond its practical tolerance point.

\section{CONCLUSION}

The antiparalleling statute, like much new legislation, is not without its questions of interpretation. The draftsmanship that went into the act was needlessly lax and the act would benefit from clarifying amendments. Nonetheless, the basic purpose of the statute is sound and may well merit extension into other areas. Public agencies should not be at liberty to extend their services without regard for the economic impact of the extension upon existing privately owned facilities. If, after considering the injury caused by construction of parallel facilities, duplication is not economical, it should be avoided. Condemnation is available if service by a public agency is considered essential. If consideration of the private injury does not affect the economic soundness of replacing rather than acquiring existing facilities, duplication may proceed, but this should not be at the expense

93. Citizens Util. Co. v. Superior Court, 59 Cal. $2 \mathrm{~d} 805,382$ P.2d 356,31 Cal. Rptr. 316 (1963); City of North Sacramento v. Citizens Util. Co., 218 Cal. App. 2d 178, 188-89, 32 Cal. Rptr. 308, 314 (3d Dist. 1963).

94. Cal. Pub. UtIL. Code ANN. \& 1417-19 (West 1956); see Citizen's Util. Co. v. Superior Court, 59 Cal. 2d 805, 809 n.3, 382 P.2d 356, 359-60 n.3, 31 Cal. Rptr. 316, 319-20 n.3 (1963); Sacramento Municipal Util. Dist. v. Pacific Gas \& Elec. Co., 72 Cal. App. 2d 638, 650-51, 165 P.2d 741, 748 (3d Dist. 1946).

95. Citizen's Util. Co. v. Superior Court, 59 Cal. 2d 805, 811, 382 P.2d 356, 361, 31 Cal. Rptr. 316, 321 (1963).

96. The right of a mutal water company to receive additional compensation for betterments added after the commencement of the proceedings should also depend on whether it was legally obliged to make such improvements. 
of the private company whose facilities are rendered useless by the duplication. There may be limits to which such a principle sliould apply, ${ }^{97}$ but certainly it should encompass property dedicated to public use that can be economically maintained ouly in the absence of duplicative facilities.

97. See Michelman, Property, Utility, and Fairness: Comments on the Ethical Foundations of "Just Compensation" Law, 80 HARv. L. REv. 1165 (1967). 